\title{
Susceptibility of Catalpa, Chilopsis, and Hybrids to Powdery Mildew and Catalpa Sphinx Larvae
}

\author{
Richard T. Olsen ${ }^{1,4}$ and Thomas G. Ranney ${ }^{2}$ \\ Department of Horticultural Science, Mountain Horticultural Crops \\ Research and Extension Center, North Carolina State University, Fletcher, \\ NC 28732-9244
}

\author{
Charles S. Hodges ${ }^{3}$ \\ Department of Plant Pathology, North Carolina State University, Raleigh, \\ NC 27695-7616
}

Additional index words. $\times$ Chitalpa tashkentensis, Macrocatalpa, Tecomeae, Bignoniaceae, Erysiphe elevata, Ceratomia catalpae, disease resistance

\begin{abstract}
A diverse collection of germplasm representing 24 taxa from Catalpa sect. Catalpa Paclt and sect. Macrocatalpa Grisebach, Chilopsis D. Don, and $\times$ Chitalpa Elias \& Wisura were screened for susceptibility to powdery mildew (PM) incited by Erysiphe elevata (Burr.) U. Braun \& S. Takam and feeding by catalpa sphinx larvae (CSL), Ceratomia catalpae (Boisduval). PM screening was conducted on plants grown in a lathhouse (50\% shade) in 2004 and a gravel pad (100\% sun) in 2005 . The PM causal organism was identified as $E$. elevata both years. Disease incidence and severity were recorded at 2-week intervals for 6 weeks and used to calculate area under the disease progress curves (AUDPC) for each year. North American Catalpa in sect. Catalpa, Chilopsis, and $\times$ Chitalpa taxa were all moderately to highly susceptible to PM. Chinese Catalpa in sect. Catalpa and West Indian species in sect. Macrocatalpa were resistant to PM. Hybrids between North American and Chinese Catalpa in sect. Catalpa varied in susceptibility, indicating transmission of partial resistance to PM. No differences in survival or growth were found in a no-choice feeding study with CSL reared on taxa from Chilopsis, $\times$ Chitalpa, or either section of Catalpa. Future breeding of $\times$ Chitalpa can use sources of PM resistance identified in this study, but a source of resistance to CSL was not found.
\end{abstract}

The genus Catalpa Scop. (Bignoniaceae Juss.) is composed of 11 species in two welldefined sections, Catalpa and Macrocatalpa, differentiated by leaf morphology and seed characteristics as well as geographic distribution (Paclt, 1952). Section Catalpa contains six species of deciduous trees with a disjunct distribution between East Asia (four species) and eastern North America (two species). All species from this section are in cultivation except $C$. tibetica Forrest, but only the two North American species are commonly cultivated as ornamental trees. Southern catalpa, C. bignonioides Walt., is native to the southeastern United States

Received for publication 24 Apr. 2006. Accepted for publication 22 July 2006.

This research was funded, in part, by the North Carolina Agricultural Research Service (NCARS), Raleigh, N.C.; North Carolina Association of Nurserymen, Inc., Raleigh, N.C.; and J. Frank Schmidt Family Charitable Foundation, Boring, Ore.

Use of trade names in this publication does not imply endorsement by the NCARS of products named nor criticism of similar ones not mentioned.

We gratefully acknowledge Tom Ward, Arnold Arboretum, Harvard University, Jamaica Plain, Mass.; Alessandro Chiari, Brooklyn Botanic Garden, Brooklyn, N.Y.; Mary Hirshfeld, Cornell
Desertwillow or desertcatalpa, Chilopsis D. Don., is a monotypic genus related to Catalpa. Chilopsis linearis (Cav.) Sweet is a small to medium-sized tree with willow-like leaves and attractive flowers in summer found in washes and arroyos in desert regions of the southwestern United States, from southern California to Texas, and south-central Mexico (Henrickson, 1985). The species and its cultivars are grown throughout its native range and adjacent regions and are valued for drought tolerance and attractive flowers (Dirr, 1998; Henrickson, 1985; Tipton, 1987).

Catalpa and Chilopsis are very similar but are differentiated by number of stamens, two in Catalpa vs. four in Chilopsis, and leaf morphology, large ovate to cordate leaves in Catalpa vs. linear to lanceolate leaves in Chilopsis. Traditional classifications have placed them in the large, pan-tropical tribe Tecomeae Endl. (Henrickson, 1985). However, this tribe was shown recently to be paraphyletic, suggesting that the tribe be divided with Catalpa (both sections) and Chilopsis forming a new tribe sister to the Oroxyleae Gentry (Olmstead, unpublished data; Spangler and Olmstead, 1999). Intergeneric hybrids between Chilopsis linearis and Catalpa bignonioides bred by Rusanov (1964) were introduced into the United States in 1977 and formally described by Elias and Wisura (1991) as $\times$ Chitalpa tashkentensis. $\times$ Chitalpa has performed well in arid climates, but suffers in more humid climates from severe powdery mildew (PM) infections (Dirr, 1998) and in eastern North America from herbivory by catalpa sphinx moth larvae, Ceratomia catalpae (Lepidoptera: Sphingidae) (T.G. Ranney, personal observation).

Powdery mildews (PM) are obligate fungal parasites (Ascomycetes) characterized by epiphytic white mycelium that often cause distortions of new growth, chlorosis, necrosis, and premature leaf fall (Braun, 1987), limiting both growth and aesthetic qualities of infected plants. Seven different species of PM have been identified on Catalpa spp. with two host-specific to Catalpa: Erysiphe catalpae Simonyan and E. elevata (syn. Microsphaera elevata Burr.) (Ale-Agha et al., 2004; Braun, 1987; Braun et al., 2002; Farr et al., 1989). Of the two Catalpa-specific PMs, only E. elevata has been reported in North America, with E. catalpae currently restricted to Europe and Asia (Braun, 1987; Sinclair et al., 1987).

Lynch, Irene Palmer, and staff of the Mountain Horticultural Crops Research and Extension Center is greatly appreciated. We thank William Swallow for statistical and James F. Walgenbach for entomologic advice. From a dissertation submitted by R.T.O. in partial fulfillment of the requirements for the $\mathrm{PhD}$ degree.

${ }^{1}$ Current address: Floral and Nursery Plants Research Unit, USDA-ARS, US National Arboretum, 3501 New York Ave. NE, Washington, DC. ${ }^{2}$ Professor.

${ }^{3}$ Professor emeritus.

${ }^{4}$ To whom reprint requests should be addressed; e-mail OlsenR@usna.ars.usda.gov. 
Catalpa sphinx moth is distributed throughout the eastern United States from New York to Florida west to Texas and Iowa overlapping with the native and naturalized range of natural host plant species $C$. bignonioides and C. speciosa (Baerg, 1935). Previous studies confirmed the suitability of Chinese Catalpa species as a food source for catalpa sphinx larvae (CSL) (Baerg, 1935; Bowers, 2003). Host plant species significantly affected larval growth (fresh weight), but survival was unaffected for larvae reared on $C$. bignonioides, C. bungei C.A. Mey, C. fargesii Bureau, C. ovata G. Don, and C. speciosa (Bowers, 2003). Ceratomia catalpae larvae sequester catalpol, converted from catalposide and other iridoid glycosides ingested from Catalpa (Bowers, 2003), which serves as a defense against generalist predators (Bowers and Puttick, 1986).

Both Catalpa and $\times$ Chitalpa are underused as ornamentals in north temperate zones, owing to a lack of diversity of available germplasm and susceptibility of the common species ( $C$. bignonioides and $C$. speciosa) to pathogens and insects, particularly PM and CSL. The susceptibility of Chilopsis and Catalpa spp. in section Macrocatalpa to PM and CSL has not previously been reported. To establish a breeding program targeting improvement of Catalpa and $\times$ Chitalpa hybrids, sources of resistance to both pest species are needed. Our objective was to assemble and screen a diverse collection of Catalpa, Chilopsis, and $\times$ Chitalpa for 1) PM susceptibility and 2) host plant suitability for CSL.

\section{Materials and Methods}

Plant material. Germplasm screened was from various botanical institutions and nurseries and accessioned at the Mountain Horticultural Crops Research and Extension Center (MHCREC), Fletcher, N.C., between 2002 and 2004, including several breeding lines from the $\times$ Chitalpa breeding program at the MHCREC (Table 1). Germplasm was received as unrooted softwood or hardwood cuttings, seed, or young plants. Plants were propagated and grown under standard nursery conditions until needed for PM and CSL studies.

Powdery mildew studies. Two separate screening studies were conducted over successive years, 2004 and 2005. In July 2004, available taxa were potted into $11.2-\mathrm{L}$ containers with a 3 pine bark: 1 peat (by volume) substrate amended with $2.8 \mathrm{~kg} \cdot \mathrm{m}^{-3}$ dolomitic limestone and $0.5 \mathrm{~kg} \cdot \mathrm{m}^{-3}$ micronutrients (Micromax; The Scotts Co., Marysville, Ohio) and top-dressed with $35 \mathrm{~g}$ per container of $15 \mathrm{~N}-3.9 \mathrm{P}-10.0 \mathrm{~K}$ controlled-release fertilizer (15-9-12 Osmocote ${ }^{\circledR}$ Plus 3-4 mo. at $70{ }^{\circ} \mathrm{C}$; The Scotts Co.). Plants were placed in a lathhouse providing $50 \%$ shade in 11 rows of $\approx 20$ plants on $0.75 \mathrm{~m}$ centers and watered as needed using drip irrigation. The experimental design was completely randomized with 19 treatments (taxa). For most taxa, $\mathrm{n} \geq 8$, except $C$. ovata 'Flavescens' $(\mathrm{n}=4)$,
Catalpa sp. \#2 (n=3), and C. bungei var. heterophylla $(\mathrm{n}=2)$.

Catalpa bignonioides stock plants were grown separately in the lathhouse and allowed to develop PM infections naturally. Beginning on 4 Aug. 2004, infected stock plants were placed in and around study plants and shaken over the study plants to release conidia every other day for 1 week (total $4 \times$ ) to supplement natural inoculation. Powdery mildew incidence (I) and severity (S) were recorded for each replicate once every 2 weeks for a total of four observation dates. Incidence (I) represented the percentage of leaves infected per plant and severity $(\mathrm{S})$ the mean percent leaf area covered with mycelium per infected leaf. After 6 weeks, when severely infected plants began abscising leaves, the study was ended.

Selected taxa from the 2004 study and several additional taxa were screened in 2005 for PM. On 23 May, plants were potted into 26.6-L containers using the substrate used in 2004 and fertilized with the same controlledrelease fertilizer at $64 \mathrm{~g}$ per container. As a result of their size, plants were removed from the lathhouse and grown on a gravel pad in full sun and watered as needed using drip irrigation. The experimental design was completely randomized with 17 treatments (taxa). For most taxa, $\mathrm{n} \geq 6$, except $C$. punctata $(\mathrm{n}=$ 5), $C$. ovata 'Flavescens' ( $\mathrm{n}=4)$, and Catalpa sp. \#2 and C. bungei var. heterophylla $(\mathrm{n}=2)$. Plants were allowed to develop infections from natural inocula; no supplemental inoculation was provided. Measurements of I and $\mathrm{S}$ were made after the first signs of PM were noted on $C$. bignonioides plants (25 July) and thereafter every 2 weeks for 6 weeks ending on 5 Sept. for a total of four observation dates.

Cleistothecia (ascomata) were collected in 2004 and 2005 from infected senescent leaves in late fall after temperatures decreased and mildew ratings were concluded. Cleistothecia were mounted in $0.01 \%$ cotton blue-lactophenol $(\mathrm{v} / \mathrm{v})$ on glass slides and viewed under a compound light microscope (Nikon Eclipse E400; Nikon Instruments, Melville, NY) at $\times 400$ magnification. Pathogen identification was based on size of cleistothecia, length and branching characteristics of cleistothecial appendages, number of asci per cleistothecium, size and shape of ascospores, and number of ascospores per ascus. Voucher specimens were made and placed in the mycological herbarium, Department of Plant Pathology, NCSU.

Area under the disease progress curves (AUDPC) were constructed for each year using the formula of Shaner and Finney (1977) with modification:

$\mathrm{AUDPC}=\sum_{i=1}^{n}\left[\left(Y_{i+1}+Y_{i}\right) / 2\right]\left[X_{i+1}-X_{i}\right]$

where $Y_{i}=\mathrm{I} \times \mathrm{S}$ at the $i$ th observation, $X_{i}=$ time (d) at the $i$ th observation, and $n=$ total number of observations. Multiplying I by $\mathrm{S}$ results in a relative disease intensity rating for a given plant at a given observation date (Seem, 1984). Then, AUDPC represents the cumulative disease intensity for a given plant over the length of the study (Jeger and Viljanen-Rollinson, 2001). Data for each year were analyzed separately. Differences between taxa were compared using analysis of variance (PROC GLM; SAS version 8.02; SAS Institute, Cary, N.C.) and means separated using Fisher protected least significant difference (LSD) at $\alpha=0.05$.

Catalpa sphinx moth larvae screening. A no-choice feeding study, with the addition of C. linearis 'Regal', was conducted in Summer 2005. On 22 June, fourth and fifth instars were collected from infested trees at the University of Georgia Horticulture Farm, Athens, Ga. Larvae were transported to the greenhouses at MHCREC and allowed to pupate in plastic boxes filled with sand and covered with perforated plastic. On 21 July, the first adult moth emerged, at which time the containers were transferred along with two stock plants of $C$. bignonioides to a mesh cage $(2 \times 2 \times 2 \mathrm{~m})$ located in a lathhouse (50\% shade). Adults emerged daily with the first egg masses laid on 23 July. Eggs were collected from the walls of the flight cage and leaves and placed in Petri dishes $(15 \mathrm{~cm})$ and then incubated in an insect-rearing room. Conditions within the rearing room were maintained at 16 hours $/ \mathrm{d}\left(15 \mu \mathrm{mol} \cdot \mathrm{s}^{-1} \cdot \mathrm{m}^{-2}\right.$ $P A R$, fluorescent lights), $25{ }^{\circ} \mathrm{C}$, and $60 \%$ relative humidity. Waxed paper cups $(0.9 \mathrm{~L})$ covered with cheesecloth served as individual rearing chambers with one cup per single plant replicate. Cups were located randomly on shelves within the chamber. Recently expanded leaves or small shoots from each taxon were placed in water picks and inserted into cups. Leaves and water were exchanged daily or as needed to maintain adequate leaf turgor and plant material for larvae.

The study began on 28 July when five first instar larvae (1-d-old) were placed in each cup. The study ended at $15 \mathrm{~d}$ when surviving larvae reached the fifth instar and feeding was negligible. Percent survival data on each taxon was recorded. For surviving larvae, final mass and headcapsule width (in millimeters) were recorded. Growth of the headcapsule was used to estimate instar stage (Baerg, 1935). Percentage survival data were arcsin-transformed before statistical analysis. The experiment was a completely randomized design with nine taxa (treatments) and eight replicates (except $C$. punctata and $C$. longissima in which $\mathrm{n}=6$ and 5 , respectively) and five subsamples (larvae) per replicate Data were analyzed using the general linear model procedure of SAS (PROC GLM; SAS version 8.02; SAS Institute).

\section{Results and Discussion}

Severe PM developed in the lathhouse in 2004 with moderate but similar pattern of infections developing in 2005 (Table 2). Infections generally began on recently expanded leaves rather than immature growth. Levels of natural inoculum in the 
Table 1. Germplasm within the tribe Tecomeae Endl. (Bignoniaceae Juss.) screened for susceptibility to powdery mildew and catalpa sphinx larvae.

\begin{tabular}{|c|c|c|c|}
\hline $\operatorname{Taxa}^{\mathrm{z}}$ & Source of plant material & Accession no. ${ }^{y}$ & Comments $^{\mathrm{x}}$ \\
\hline \multicolumn{4}{|l|}{ Catalpa Section Catalpa Paclt } \\
\hline bignonioides 'Koehnei' & Sir Harold Hillier Gard., Hampshire, UK & 1976.9778 & $\begin{array}{l}\text { New growth broadly margined with yellow, c. } 1903 \text {. } \\
\text { Syn. 'Aureo-marginata' }\end{array}$ \\
\hline C. bungei var. heterophylla C.A. Mey. & Brooklyn Bot. Gard., Brooklyn, N.Y. & 340008 & $\begin{array}{l}\text { Lobed Manchurian catalpa; unknown provenance; } \\
\text { form grows with type species in the wild, } \\
\text { c. } 1907 . \text { N. China }\end{array}$ \\
\hline C. Xerubescens Carr. 'J.C. Teas' & Cornell Plantations, Ithaca, N.Y. & $97-072$ & $\begin{array}{l}\text { Teas' hybrid catalpa }(\text { C. ovata } \times \text { bignonioides }) \\
\text { spontaneous hybrid occurring before } 1869 \text { in } \\
\text { France and } 1874 \text { in the US }\end{array}$ \\
\hline Xerubescens 'Purpurea' & MHCREC & $1996-139$ & $\begin{array}{l}\text { Purple-leaf catalpa; new growth dark purple, fades } \\
\text { to green, discovered in cultivation c. } 1886 \text { in US }\end{array}$ \\
\hline C. ovata G. Don & Arnold Arboretum & $516-87 \mathrm{~B}$ & $\begin{array}{l}\text { Chinese catalpa; received as wild collected seed } \\
\text { from Yunnan Inst. Trop. Bot., China as } \\
\text { C. fargesii f. duclouxii }\end{array}$ \\
\hline ovata 'Flavescens' & Sir Harold Hillier Gard. & $1992-1036$ & $\begin{array}{l}\text { Pale yellow Chinese catalpa; smaller, more yellow } \\
\text { flowers than the species, c. } 1863 \text { in Europe }\end{array}$ \\
\hline $\begin{array}{l}\text { C. speciosa (Ward. ex Barn.) } \\
\text { Ward. ex Engelm. }\end{array}$ & Arnold Arboretum & $1245-79-B$ & $\begin{array}{l}\text { Northern catalpa; cuttings of a wild tree from Mo., } \\
\text { U.S. Native to south-central US }\end{array}$ \\
\hline C. sp. \#1 & Morton Arboretum, Lisle, Ill. & $498-8003-79$ & $\begin{array}{l}\text { Cuttings of a plant raised from seed received from } \\
\text { the Bot. Gard. at Uzbek Acad. of Sciences, } \\
\text { Tashkent, Uzbekistan as C. bungei C.A. Mey but } \\
\text { appears to be of hybrid origin }\end{array}$ \\
\hline C. punctata Griseb. & Fairchild Tropical Bot Gard. & $66396 \mathrm{C}$ & $\begin{array}{l}\text { Cuban catalpa; seedlings of a tree in the Bahamas; } \\
\text { native to Cuba, rare in cultivation }\end{array}$ \\
\hline \multicolumn{4}{|l|}{ Chilopsis D. Don } \\
\hline Chilopsis linearis (Cav.) Sweet 'Bubba' & $\begin{array}{l}\text { SFA Mast Arboretum, } \\
\text { Nacogdoches, Texas }\end{array}$ & NA & $\begin{array}{l}\text { Bubba desertwillow; popular cultivar with deep } \\
\text { purple flowers, introduced by Paul Cox of San } \\
\text { Antonio Bot. Gard., Texas }\end{array}$ \\
\hline C. linearis 'Regal' & $\begin{array}{l}\text { Native Texas Nursery, Austin, } \\
\text { Texas }\end{array}$ & NA & $\begin{array}{l}\text { Regal desertwillow; lavendar flower with burgundy } \\
\text { lower lip; introduced by Los Lunas Plant Material } \\
\text { Center, N.M. in } 1989\end{array}$ \\
\hline \multicolumn{4}{|l|}{$\begin{array}{l}\times \text { Chitalpa }(\text { Chilopsis linearis } \times \\
\text { Catalpa bignonioides) }\end{array}$} \\
\hline $\begin{array}{l}\times \text { Chitalpa tashkentensis Elias \& } \\
\text { Wis. 'Morning Cloud' }\end{array}$ & $\begin{array}{l}\text { Forestfarm Nursery, Williams, } \\
\text { Ore. }\end{array}$ & $2005-311$ & $\begin{array}{l}\text { Morning Cloud chitalpa; white-flowered cultivar } \\
\text { named in 1991; one of two clones introduced from } \\
\text { Uzbekistan in } 1977\end{array}$ \\
\hline$\times$ C. tashkentensis 'Pink Dawn' $2 x$ & MHCREC & $2005-312$ & $\begin{array}{l}\text { Diploid Pink Dawn chitalpa; pink-flowered cultivar } \\
\text { named in 1991; one of two clones introduced } \\
\text { from Uzbekistan in } 1977\end{array}$ \\
\hline$\times$ C. tashkentensis 'Pink Dawn' $4 x$ & MHCREC & NA & $\begin{array}{l}\text { Oryzalin-induced tetraploid form of } \\
\text { 'Pink Dawn' chitalpa }\end{array}$ \\
\hline$\times$ C. tashkentensis $\mathrm{F}_{2} 4 x$ seedlings & MHCREC & NA & $\begin{array}{l}\text { Seedlings from selfed tetraploid } \\
\text { 'Pink Dawn' chitalpa }\end{array}$ \\
\hline$\times C$. tashkentensis MHCREC\#1 & MHCREC & H2004-003 & $\begin{array}{l}\text { Diploid seedling from Chilopsis 'Bubba' } \times 24-2-1 \\
\text { 'Pink Dawn' }(2 x+4 x) \text { cytochimera }\end{array}$ \\
\hline
\end{tabular}

${ }^{2}$ Author of scientific name follows the first listing of each taxon above the rank of cultivar unless the taxon is solely represented by a cultivar(s).

${ }^{\mathrm{y}}$ Accession number from the original source, if available; NA, no accession number.

${ }^{\mathrm{x}}$ Accession information, including taxa description, origin, and date of introduction or discovery. 
Table 2. Mean area under the disease progress curve for powdery mildew infection among a diverse collection of taxa within the tribe Tecomeae Endl. (Bignoniaceae Juss.) grown in containers under nursery conditions during 2004 and 2005.

\begin{tabular}{|c|c|c|c|}
\hline \multirow{2}{*}{ Taxa } & & \multicolumn{2}{|c|}{$\mathrm{AUDPC}^{\mathrm{z}}$} \\
\hline & & $2004^{y}$ & $2005^{x}$ \\
\hline \multirow[t]{5}{*}{$\times$ Chitalpa tashkentensis } & MHREC\#1 & $2416 \mathrm{a}^{w}$ & $-^{\mathrm{v}}$ \\
\hline & Pink Dawn $4 x$ & $2300 \mathrm{a}$ & $1167 \mathrm{c}$ \\
\hline & Pink Dawn $2 x$ & $2290 \mathrm{a}$ & $2154 \mathrm{a}$ \\
\hline & $\mathrm{F}_{2} 4 x$ seedlings & $2268 \mathrm{a}$ & - \\
\hline & Morning Cloud & $1300 \mathrm{~b}$ & $1655 \mathrm{~b}$ \\
\hline Catalpa bignonioides & Nana & $1270 \mathrm{~b}$ & - \\
\hline C. speciosa & & $1134 \mathrm{~b}$ & - \\
\hline C. ×erubescens & J.C. Teas & $914 \mathrm{c}$ & $1261 \mathrm{c}$ \\
\hline C. bignonioides & & $694 \mathrm{~d}$ & $172 \mathrm{~d}$ \\
\hline C. bignonioides & Koehnei & $637 \mathrm{~d}$ & - \\
\hline C. sp. & $\# 2$ & $622 \mathrm{~d}$ & $90 \mathrm{~d}$ \\
\hline C. bignonioides & Aurea & $273 \mathrm{e}$ & - \\
\hline Chilopsis linearis & Bubba & - & $48 \mathrm{~d}$ \\
\hline C. ×erubescens & Purpurea & $24 \mathrm{f}$ & $33 \mathrm{~d}$ \\
\hline C. sp. & $\# 1$ & $15 \mathrm{f}$ & 0 \\
\hline C. × galleana & & $4 \mathrm{f}$ & $1 \mathrm{~d}$ \\
\hline C. sp. & \#3 & - & 0 \\
\hline C. bungei & var. heterophylla & 0 & 0 \\
\hline C. fargesii & var. duclouxii & 一 & 0 \\
\hline C. ovata & & 0 & 0 \\
\hline C. ovata & Flavescens & 0 & 0 \\
\hline C. longissima & & 0 & 0 \\
\hline C. punctata & & - & 0 \\
\hline
\end{tabular}

${ }^{\mathrm{z}}$ Area under the disease progress curve (AUDPC) calculated as the product of disease incidence (\% leaves affected) and severity (\% leaf area affected).

yPlants grown under $50 \%$ shade with drip irrigation. $\mathrm{n} \geq 8$ except $C$. ovata 'Flavescens' $(\mathrm{n}=4), C$. sp. \#2 $(\mathrm{n}=3)$, and C. bungei var. heterophylla $(\mathrm{n}=2)$.

'Plants grown in full sun with drip irrigation. $n \geq 6$ except $C$. punctata $(n=5), C$. ovata 'Flavescens' $(n=4)$, C. sp. \#2 $(\mathrm{n}=3)$, and C. bungei var. heterophylla $(\mathrm{n}=2)$.

wMeans within a year followed by the same letter are not significantly different based on Fisher's LSD 0.05 . 'Dropped from study in 2005 or not available in 2004

proximity of MHCREC were assumed to be high with epiphytotic events observed in the years before 2004 on $\times$ Chitalpa tashkentensis 'Pink Dawn' growing at MHCREC (personal observation). White superficial mycelium on the leaf surface was well developed and heavy cleistothecial development in the fall of 2004 facilitated identification of the causal organism. Length and branching of cleistothecial appendages are key taxonomic characters for distinguishing Erysiphe spp. (Ale-Agha et al., 2004; Braun, 1987). Cleistothecial appendages were hyaline, 4 to $7 \times$ longer than the width of the cleistothecial body and dichotomously branched at the terminus, characteristic of Erysiphe elevata. Erysiphe catalpae has nonbranched appendages, and E. penicillata [syn. Microsphaera penicillata (Wallr.:Fr.) Lév.], a broadly adapted PM in North America, has branched appendages 1 to $1.5 \times$ as long as the width of the cleistothecial body (Braun, 1987). In North America, E. elevata (including synonyms Microsphaera vaccinii auct. p. p. and M. alnii var. vaccinii auct. p. p.) is the most commonly reported PM on Catalpa spp. (Braun, 1987; Sinclair et al., 1987), but our collection and positive identification was the first for North Carolina. In Europe, E. catalpae is the common Catalpa-specific PM (Ale-Agha et al., 2004; Braun, 1987). However, E. elevata was recently reported in Hungary (Vajna et al., 2004) and is currently spreading in Europe (Ale-Agha et al., 2004; Cook et al., 2004).
There were significant differences among taxa in susceptibility to PM as measured by AUDPC values in 2004 (F value $=183.4, P<$ $0.0001)$ and $2005(\mathrm{~F}$ value $=51.6, P<$ $0.0001)$. Taxa with no PM infection (0 AUDPC) were not used in determining differences among means using Fisher protected LSD. The natural host species for E. elevata, N. American C. bignonioides and C. speciosa, had intermediate levels of PM infection in 2004. All three cultivars of $C$. bignonioides ('Aurea', 'Koehnei', and 'Nana') likewise were susceptible, although 'Nana' was more susceptible than the other cultivars and type species (Table 2). All of these were dropped from the 2005 study, except C. bignonioides, that served as a susceptible control both years.

The Chinese species C. bungei var. heterophylla, C. ovata, and C. ovata 'Flavescens' were resistant to E. elevata in both study years. Catalpa fargesii var. duclouxii was not available in 2004 but was resistant during 2005. These taxa appear to be useful in breeding for PM resistance. The behavior of C. sp. \#1, \#2, and \#3, received as C. bungei, is of special note. Catalpa bungei is confused in the nursery trade and herbaria with $C$. bignonioides 'Nana' and C. ovata (Bean, 1936; Dirr, 1998; Paclt, 1952). Catalpa sp. \#1 and \#2 were received from Morton Arboretum, Lisle, Ill., as unrooted cuttings from plants grown from seed received as $C$. bungei from the Uzbek Academy of Sciences Botanical Garden, Tashkent, Uzbekistan (Table 1).
These plants do not fit the description of C. bungei by Paclt (1952) nor Bean (1936), in that leaves are not glabrous, inflorescences are not corymb-like, and flowers are not rosecolored. Catalpa and Chilopsis are self-incompatible (Petersen et al., 1982; Stephenson and Thomas, 1977); therefore, trueness-totype may be questioned in seed of cultivated origin. These plants appear to be hybrids with C. bignonioides, although this cross has not been reported previously. In terms of PM susceptibility, they responded similarly to cultivars of $C$. Xerubescens $(C$. ovata $\times C$. bignonioides) with moderate to low levels of susceptibility in both 2004 and 2005 (Table 2). Catalpa sp. \#3 represented nursery collected seed and was identical to C. ovata in foliage and flower. It was available only for 2005 , and in that year was resistant to E. elevata, as were the other taxa of C. ovata (Table 2). In our study, C. bungei var. heterophylla from the Brooklyn Botanic Garden was the only $C$. bungei taxon that matched its taxonomic description: leaves were dark green and glabrous and differed from the type species only in its more deeply lobed leaves (Paclt, 1952). Although we only had two plants, this taxon remained free of PM infection both years.

Hybrids between Chinese $C$. ovata and $\mathrm{N}$. American C. bignonioides ( $C$. xerubescens) and $C$. speciosa ( $\times$ galleana) exhibited a broad range of susceptibility to E. elevata. Of the hybrids, $C$. Xerubescens 'J.C. Teas' was most susceptible in both 2004 and 2005 (AUDPC of 914 and 1261, respectively) followed by C. Xerubescens 'Purpurea' (24 and 33, respectively) and $C$. × galleana (4 and 1 , respectively). Our clone of $C$. Xerubescens 'J.C. Teas' resembles the $C$. bignonioides parent, whereas $C$. Xerubescens 'Purpurea' resembles the $C$. ovata parent. In the United States, C. Xerubescens was first documented by Sargent (1889) who reported the existence of hybrid seedlings sent to the Arnold Arboretum by a Mr. J. C. Teas of Carthage, Ind. The origin of the cultivar 'J.C. Teas' is unknown but may represent one of the original $\mathrm{F}_{1}$ hybrids sent to the Arnold Arboretum or an $\mathrm{F}_{2}$ segregate derived from the original hybrids. Segregates were known to exist (Jones and Filley, 1920; Paclt, 1952; Sargent, 1889) and the greater susceptibility of 'J.C. Teas' to PM infection may reflect segregation toward susceptibility of $C$. bignonioides to E. elevata, and for $C$. xerubescens 'Purpurea' segregation toward resistance in $C$. ovata (Table 2). Catalpa $\times$ galleana had extremely low levels of PM infection in both years with only a few spots noted on the new growth and no secondary infection or spread (Table 2). Our clone of Galle's hybrid catalpa is one of the original $\mathrm{F}_{1}$ hybrid seedlings bred by Karl Sax at the Arnold Arboretum in 1940 (Table 1). Morphologically, the hybrid is intermediate between $C$. ovata and $C$. speciosa but has the largest leaves of the genus (personal observation). The lack of complete resistance in $C$. × galleana, a known $\mathrm{F}_{1}$, and the range of susceptibilities in $C$. Xerubescens clones 
suggests inheritance of PM resistance in Catalpa is polygenic or quantitative in nature. Evergreen species of sect. Macrocatalpa, C. longissima, and C. punctata were resistant to PM infection by E. elevata. Section Macrocatalpa is restricted to the New World with five poorly understood species occurring throughout the West Indies (Paclt, 1952). Little cultural information existed for these taxa with the exception of $C$. longissima, an important agro-forest tree species in Haiti. In seedling nurseries, leaf spots and anthracnose have been reported (Francis, 1990), but reports of PM infections on this species or other West Indian species was lacking in the literature.

Although Chilopsis taxa were not available for the 2004 study, in 2005, PM infections developed late on $C$. linearis 'Bubba' grown in full sun. Thus, the low AUDPC values recorded for this taxon (Table 2). Our limited data suggest that some Chilopsis taxa are not resistant to PM infection by $E$. elevata, but the degree of susceptibility needs further investigation.

$\times$ Chitalpa cultivars were among the most susceptible taxa in both 2004 and 2005 . Infection and spread of mycelia were rapid as noted by the high AUDPC values for $\times$ Chitalpa's in both years (Table 2 ). Powdery mildew infections on $\times$ Chitalpa have been observed previously in Georgia (Dirr, 1998), Arkansas (J. Lindstrom, personal communication), and North Carolina (T. Ranney, personal observation), but the causal organism was not identified. In both years, $\times$ Chitalpa 'Pink Dawn' was more susceptible than 'Morning Cloud' (Table 2). The induced allotetraploid 'Pink Dawn' was as susceptible to PM infection as the diploid 'Pink Dawn' in 2004, but in 2005 had significantly less PM. Also, progeny derived from allotetraploid 'Pink Dawn' (MHREC \#1 and $\mathrm{F}_{2} 4 x$ seedlings) were highly susceptible to PM (Table $2)$. The progeny were uniform in appearance and susceptibility, which suggests that these allopolyploids have fixed heterozygosity (strong disomic pairing) resulting in little intergenomic recombination and segregation.

There were no significant differences for CSL survival $(\mathrm{F}$ value $=1.74, P=0.113)$, final weight $(\mathrm{F}$ value $=2.09, P=0.173)$, or

Table 3. Survival and final growth measurements for Ceratomia catalpae larvae on a known host (Catalpa bignonioides) and nonhost members of the Tecomeae tribe (Bignoniaceae) in a 15-d no-choice feeding study.

\begin{tabular}{|c|c|c|c|c|}
\hline \multirow[b]{2}{*}{$\operatorname{Taxa}^{\mathrm{z}}$} & & \multicolumn{3}{|c|}{ Larvae } \\
\hline & & Survival $(\%)^{y}$ & Final wt $(g)^{x}$ & Head width $(\mathrm{mm})^{\mathrm{w}}$ \\
\hline C. bignonioides & & 59.5 & 1.4 & 3.7 \\
\hline C. longissima & & 84.1 & 2.0 & 4.1 \\
\hline C. ovata & & 47.5 & 2.2 & 4.0 \\
\hline C. punctata & & 70.7 & 1.5 & 3.9 \\
\hline Chilopsis linearis & Bubba & 70.7 & 1.6 & 3.6 \\
\hline Chilopsis linearis & Regal & 78.1 & 1.1 & 3.8 \\
\hline \multirow[t]{3}{*}{$\times$ Chitalpa tashkentensis } & Morning Cloud & 45.6 & 1.7 & 3.9 \\
\hline & Pink Dawn $2 x$ & 27.3 & 1.3 & 3.4 \\
\hline & Pink Dawn $4 x$ & 44.0 & 2.5 & 3.9 \\
\hline
\end{tabular}

${ }^{\mathrm{z}} \mathrm{n}=8$ except $C$. punctata $(\mathrm{n}=6)$ and C. longissima $(\mathrm{n}=5)$.

${ }^{\mathrm{y}}$ Began with five larvae per replicate. Arcsin transformed for data analysis, untransformed data presented. Not significant $(\mathrm{F}=1.74, P=0.113)$.

${ }^{x}$ Final weight measured on d 15 before pupation. Not significant $(\mathrm{F}=2.09, P=0.173)$.

${ }^{\mathrm{w}}$ Width measured across head capsule at day 15 (fifth instars $\left.\approx 4.0 \mathrm{~mm}\right)$. Not significant $(\mathrm{F}=0.65, P=0.723)$. causal organism of PM on study plants of Catalpa sect. Catalpa and $\times$ Chitalpa. Cultivars and hybrids derived from $\times$ Chitalpa tashkentensis were especially susceptible. Taxa of Chinese Catalpa in sect. Catalpa and West Indian evergreen species in sect. Macrocatalpa were resistant. Existing hybrids between susceptible and resistant species $(C$. Xerubescens and $C$. × galleana) demonstrated transmission of partial resistance to PM. Catalpa species from sect. Macrocatalpa will be an alternative source of resistance for introgression of PM resistance into novel hybrids of Catalpa and $\times$ Chitalpa. Also, C. linearis was susceptible to PM infection by E. elevata; thus, its value to breeding programs will lie in introducing novel flower color, drought tolerance, refined foliage, and reduced height to new $\times$ Chitalpa cultivars. Unfortunately, no immediate source of resistance to CSL was found in existing germplasm, indicating that whereas Ceratomia catalpae is monophagous on Catalpa in the eastern United States, its sister genus Chilopsis in southwestern United States is also a suitable host.

\section{Literature Cited}

Ale-Agha, N., A. Bolay, U. Braun, B. Feige, H. Jage, V. Kummer, A. Lebeda, M. Piatek, H.-D. Shin, and K. Zimmermannova-Pastircakova. 2004. Erysiphe catalpae and Erysiphe elevata in Europe. Mycol. Prog. 3:291-296.

Baerg, W.J. 1935. Three shade tree insects, II. Great elm leaf-beetle, Catalpa sphinx, and Eastern tent caterpillar. Arkansas Agr. Expt. Sta. Bul. 317:3-28.

Bean, W.J. 1936. Trees and shrubs hardy in the British Isles. Vol. 1. John Murray, London.

Bowers, M.D. 2003. Hostplant suitability and defensive chemistry of the Catalpa sphinx, Ceratomia catalpae. J. Chem. Ecol. 29:2359-2367.

Bowers, M.D. and G.M. Puttick. 1986. Fate of ingested iridoid glycosides in Lepidopteran herbivores. J. Chem. Ecol. 12:169-178.

Braun, U. 1987. A monograph of the Erysiphales (powdery mildews). Beihefte zur Nova Hedwigia 89:1-700.

Braun, U., R.T.A. Cook, A.J. Inman, and H.-D Shin. 2002. The taxonomy of the powdery mildew fungi, p. 13-55. In: R.R. Bélanger, W.R. Bushnell, A. Dik, and T.L.W. Carver (eds.). The powdery mildews: a comprehensive treatise. Amer. Phytopathol. Soc, St. Paul, Minn.

Cook, R.T.A., B. Henricot, and L. Kiss. 2004. First record of Erysiphe elevata on Catalpa bignonioides in the UK. Plant Pathol. 53:807.

Dirr, M.A. 1998. Manual of woody landscape plants: their identification, ornamental characteristics, culture, propagation and uses. Stipes, Champaign, Ill.

Elias, T.S. and L.F. Newcombe. 1979. Foliar nectarines and glandular trichomes in Catalpa (Bignoniaceae). Acta Bot. Sin. 21:215-224.

Elias, T.S. and W. Wisura. 1991. $\times$ Chitalpa tashkentensis (Bignoniaceae), an intergeneric hybrid of ornamental value. Baileya 23:139-144.

Farr, D.F., G.F. Bills, G.P. Chamuris, and A.Y. Rossman. 1989. Fungi on plants and plant products in the United States. The American Phytopathololgical Society, St. Paul, Minn.

Francis, J.K. 1990. Catalpa longissima (Jacq.) Dum. Cours., yokewood, p. 4. Silvics Manual SO-ITF-SM-37. USDA For. Serv, Southern For. Expt. Sta., New Orleans. 
Henrickson, J. 1985. A taxonomic revision of Chilopsis (Bignoniaceae). Aliso 11:179-197.

Jeger, M.J. and S.L.H. Viljanen-Rollinson. 2001. The use of the area under the disease-progress curve (AUDPC) to assess quantitative disease resistance in crop cultivars. Theor. Appl. Genet. 102:32-40.

Jones, D.F. and W.O. Filley. 1920. Teas' hybrid Catalpa. J. Hered. 11:16-24.

Nayar, J.K. and G. Fraenkel. 1963. The chemical basis of the host selection in the Catalpa Sphinx, Ceratomia catalpae (Lepidopteran, Sphingidae). Ann. Entomol. Soc. Am. 56:119-122.

Paclt, J. 1952. Synopsis of the genus Catalpa (Bignoniaceae) III. Candollea 13:241-285.

Petersen, C., J.H. Brown, and A. Kodric-Brown 1982. An experimental study of floral display and fruit set in Chilopsis linearis (Bignoniaceae). Oecologia 55:7-11.

Rehder, A. 1940. Manual of cultivated trees and shrubs hardy in North America exclusive of the subtropical and warmer temperate regions. Macmillan, NY.

Rusanov, N.F. 1964. On the intergeneric hybrids of Catalpa and Chilopsis. Bul. Main Bot. Gard. Moscow 55:44-47 (in Russian).

Sargent, C.S. 1889. A hybrid Catalpa. Garden and Forest 2:303-305.

Seem, R.C. 1984. Disease incidence and severity relationships. Annu. Rev. Phytopath. 22:133-150.

Shaner, G. and R.E. Finney. 1977. The effect of nitrogen fertilization on the expression of slowmildewing resistance in Knox wheat. Phytopathology 67:1051-1056.
Sinclair, W.A., H.H. Lyon, and W.T. Johnson 1987. Diseases of trees and shrubs. Comstock Publishing Associates, Ithaca, NY

Spangler, R.E. and R.G. Olmstead. 1999. Phylogenetic analysis of Bignoniaceae based on the cpDNA gene sequences $r b c \mathrm{~L}$ and $n d h \mathrm{~F}$. Ann. Mo. Bot. Garden 86:33-46.

Stephenson, A.G. and W.W. Thomas. 1977. Diurnal and nocturnal pollination of Catalpa speciosa (Bignoniaceae). Syst. Bot. 2:191-198.

Tipton, J.L. 1987. Variation in desert willow flower and leaf size. HortScience 22:938-939.

Vajna, L., G. Fischl, and L. Kiss. 2004. Erysiphe elevata (syn. Microsphaera elevata), a new North American powdery mildew fungus in Europe infecting Catalpa bignonioides trees. Plant Pathol. 53:244. 